\title{
REACTION OF SORGHUM GENOTYPES TO THE ANTHRACNOSE FUNGUS Colletotrichum graminicola
}

\author{
CARLOS R. CASELA, FREDOLINO G. SANTOS \& ALEXANDRE S. FERREIRA
}

Embrapa Milho e Sorgo, Cx. Postal 151, CEP 35701-970, Sete Lagoas, MG, e-mail: casela@cnpms.embrapa.br

(Accepted for publication 04/04/2001)

Corresponding author: Carlos R. Casela

CASELA, C. R., SANTOS, F. G. \& FERREIRA, A. S. Reaction of sorghum genotypes to the anthracnose fungus Colletotrichum graminicola. Fitopatologia Brasileira 26:197-200. 2001.

\begin{abstract}
The reactions of 22 sorghum (Sorghum bicolor) genotypes to six previously identified races of the sorghum anthracnose fungus Colletotrichum graminicola, were evaluated under greenhouse and field conditions. Races were inoculated in separate tests in the greenhouse. In the field, spreader rows of a susceptible genotype were

artificially inoculated with a mixture of the six races of the pathogen. In the greenhouse tests, nine genotypes showed resistance to all six races. In the field high levels of dilatory resistance was observed in the sorghum genotypes CMSXS169 and CMSXS373.

Key words: Sorghum bicolor, host plant resistance.

RESUMO

\section{Reação de genótipos de sorgo a Colletotrichum graminicola, agente causal da antracnose em sorgo}

Foi avaliada a reação de 22 genótipos de sorgo (Sorghum bicolor) ao patógeno Colletotrichum graminicola, agente causal da antracnose. Em casa de vegetação, os genótipos foram inoculados separadamente com seis raças, previamente identificadas do patógeno. No campo, foi

realizada uma inoculação com uma mistura das seis raças em uma linha suscetível utilizada como fonte de inóculo. Nove genótipos foram totalmente resistentes às seis raças inoculadas em casa de vegetação. Alta resistência dilatória foi identificada nos genótipos CMSXS169 e CMSXS373.
\end{abstract}

\section{INTRODUCTION}

Anthracnose, caused by the fungus Colletotrichum graminicola (Ces.) Wils. (Syn. C. sublineolum Henn in Kab. \& Bubák), is one of the most important diseases of sorghum [Sorghum bicolor (L.) Moench] in Brazil. The disease reduces yield of sorghum crops and is particularly damaging under warm and humid conditions (Ali \& Warren, 1987). The pathogen infects all aboveground parts of the plant, leaf, stem, peduncle, panicle, and grain, but the leaf phase of the disease is more important for its capacity to reduce yields of sorghum grains and fodder by $50 \%$ or more, depending on the susceptibility of the cultivar and the severity of the epidemics (Harris \& Johnson, 1964; Ferreira \& Warren, 1982).

Genetic resistance to $C$. graminicola has not been stable in certain situations due to the high variability present in the pathogen population (Cardwell et al., 1989). The instability of race specific resistance has promoted the search for more stable forms of resistance. Dilatory resistance, characterized by a slow rate of disease development has been demonstrated in this pathosystem (Cardwell et al., 1998; Casela et al., 1993; Guimarães et al., 1998b). Other alternative strategies have been explored to obtain stable resistance to $C$. graminicola, such as the development of sorghum hybrids resulting from the combination of male - sterile (A) and restorer $(\mathrm{R})$ lines against which there is no virulence association in the pathogen population (Casela et al., 1998) and the use of cultivar mixtures (Guimarães et al., 1998a). A continuous process of identification of sources of resistance to this pathogen is needed not only to be incorporated in breeding programs, but also to be explored in management strategies to increase the stability of this resistance.

The objective of this study was to identify sources of resistance to C. graminicola, through the evaluation of the reactions of 21 sorghum genotypes to six races of the pathogen inoculated in greenhouse and field experiments.

\section{MATERIAL AND METHODS}

This study was conducted using field, greenhouse, and laboratory facilities of Embrapa Maize and Sorghum Research Center in Sete Lagoas, MG, Brazil aiming to evaluate the reaction of $15 \mathrm{~B}$ and $\mathrm{R}$ elite lines and six experimental hybrids (Table 1) for resistance to six races of $C$. graminicola.

\section{Greenhouse tests}

Sorghum genotypes were planted in a randomized complete block design with three replications of five plants 
TABLE 1 - Origin number or pedigree of sorghum (Sorghum bicolor) accessions evaluated for resistance to Colletotrichum graminicola

\begin{tabular}{lc}
\hline \hline Sorghum Accession & Original Number of Pedigree \\
\hline CMSXS201 & V-20-1-1-1 \\
CMSXS202 & Tx628B \\
CMSXS203 & Tx629B \\
CMSXS204 & Tx630B \\
CMSXS206 & Tx632B \\
CMSXS208 & 5DX61/6/2 \\
CMSXS210 & PU932247B \\
CMSXS211 & IS01873B \\
CMSXS212 & PUGP37B \\
CMSXS213 & SPV387 \\
CMSXS214 & SPV475 \\
CMSXS157 & Tx1399B \\
CMSXS169 & BR011R \\
CMSXS178 & SC748-5RX SC326-6R \\
CMSXS182 & BRP3RXSC326-6R \\
CMSXS3721 & CMSXS101AXCMSXS169R \\
CMSXS3731 & CMSXS157AXCMSXS180R \\
CMSXS3741 & CMSXS157AXCMSXS182R \\
CMSXS3751 & CMSXS210AXCMSXS116R \\
CMSXS3761 & CMSXS210AXCMSXS178R \\
CMSXS3771 & CMSXS210AXCMSXS180R \\
BR009 & Tx523 \\
\hline 1- Sorghum hybrid &
\end{tabular}

1- Sorghum hybrid

per replication. Six races of $C$. graminicola, previously identified as races 31A, 31B, 31C, 29E, 31E, and 29F (Casela \& Ferreira, 1987), obtained from experimental fields in Sete Lagoas and in Pelotas, RS, were used in this study, and the experiment was repeated twice.

Inoculum of each race was obtained by flooding sevenday-old cultures, grown on oat meal agar (OMA) plates under continuous fluorescent light at a temperature of $25{ }^{\circ} \mathrm{C}$, with sterile distilled water, dislodging the conidia with a scalpel, and passing the conidial suspension of each isolate through two layers of cheesecloth to separate mycelia. The filtered suspension was adjusted to a concentration of $10^{6}$ conidia/ $\mathrm{ml}$. Tween 20 (3 drops/l) was added to each suspension as a wetting agent. Inoculum was applied to the leaf surface of 30day-old plants with a hand sprayer. Plants were incubated for $18 \mathrm{~h}$ in a dew deposition chamber at $100 \%$ relative humidity.

Plants were evaluated for infection type 12 days after inoculation using the following 1-to-5 scale:

1 - presence of chlorotic flecks;

2 - red spots on the leaf lamina;

3 - necrotic lesions, sometimes elongated, but no acervuli formed;

4 - necrotic lesions formed with acervuli present in the center;

5 - necrotic lesions, sometimes coalescing with abundant formation of acervuli.

Symptoms were separated into two classes of reactions: $\mathrm{R}=$ resistant (including infection types 1,2 , and 3 ) and $\mathrm{S}=$ susceptible (including infection types 4 and 5).

\section{Field Experiments}

Experiments were planted on December 20, 1998 and January 10, 1999. Sorghum genotypes were evaluated in two experiments with 12 treatments each. Genotypes CMSXS210 (resistant to all races in the greenhouse tests) and BR009 were included in both experiments as resistant and susceptible checks, respectively. A randomized complete block design with three replications was adopted in both years. Genotypes were planted in single-row plots, separated by two rows of the resistant line SC283 to reduce interplot infection. Rows were $5.0 \mathrm{~m}$ long and $1.0 \mathrm{~m}$ apart with 15 plants $/ \mathrm{m}$. A block of $1.0 \mathrm{~m}$ spreader rows, formed by the susceptible cultivar Tx623 was planted $0.5 \mathrm{~m}$ apart in front of each replication. The isolation among replications was made through a $1.0 \mathrm{~m}$ range of the resistant genotype SC283.

Inoculum was prepared as previously described for the greenhouse experiments and applied with a pressurized sprayer on the $1.0 \mathrm{~m}$ spreader rows in the proportion of approximately $100 \mathrm{ml} / \mathrm{m}$. In both years, plants were inoculated at 50 days after sowing with a spore suspension at the concentration of $10^{6}$ conidia $/ \mathrm{ml}$. Plants were inoculated with a mixture, in equal proportions, of the same races inoculated in the greenhouse. The same isolates were used in field and greenhouse experiments.

Disease severity (percentage of leaf area covered by lesions) was estimated on a 0-to-9 rating scale, according to Sharma (1983). Ratings were taken on a weekly basis, starting seven days after inoculation, at three different points in each plot: $0.5 \mathrm{~m}, 3.5 \mathrm{~m}$, and $5.5 \mathrm{~m}$ from the source of inoculum. The disease severity data taken from each point of evaluation, were used to calculate an average AUDPC value in each plot, according to Torres \& Ventura (1991).

\section{RESULTS AND DISCUSSION}

\section{Greenhouse evaluations}

Resistant reactions were variable from hypersensitive type symptom, characterized by chlorotic flecks, to the presence of necrotic elongated lesions without the presence of fruiting bodies. Nine lines out of the 21 tested, were resistant to all races inoculated in the greenhouse (Table 2). Genotypes CMSXS157, CMSXS203, CMSXS206, and CMSXS212 were susceptible and CMSXS182, CMSXS208, CMSXS210, CMSXS213, CMSXS372, CMSXS374, CMSXS375, CMSXS376, and CMSXS377 were resistant to all races. The remaining eight genotypes responded differentially to the six races inoculated.

\section{Field evaluations}

A large variation in the level of dilatory resistance was observed among the sorghum genotypes in the field. Genotypes CMSXS208 (Table 3), CMSXS182, CMSXS375, CMSXS376, CMSXS377 (Table 4), and the control CMSXS210 developed hypersensitive reaction in the two years of evaluation, and their AUDPC values reflect the intensity of chlorotic flecks or elongated non-sporulating 
TABLE 2 - Reaction of sorghum (Sorghum bicolor) genotypes to six races of Colletotrichum graminicola

\begin{tabular}{lcccccc}
\hline \hline Sorghum & \multicolumn{5}{c}{ Race/Reaction $^{1}$} \\
\cline { 2 - 7 } genotype $^{2}$ & 31A & 31B & 31C & 29E & 31E & 29F \\
\hline CMSXS182 & $\mathrm{R} 1$ & $\mathrm{R}$ & $\mathrm{R}$ & $\mathrm{R}$ & $\mathrm{R}$ & $\mathrm{R}$ \\
CMSXS208 & $\mathrm{R}$ & $\mathrm{R}$ & $\mathrm{R}$ & $\mathrm{R}$ & $\mathrm{R}$ & $\mathrm{R}$ \\
CMSXS210 & $\mathrm{R}$ & $\mathrm{R}$ & $\mathrm{R}$ & $\mathrm{R}$ & $\mathrm{R}$ & $\mathrm{R}$ \\
CMSXS213 & $\mathrm{R}$ & $\mathrm{R}$ & $\mathrm{R}$ & $\mathrm{R}$ & $\mathrm{R}$ & $\mathrm{R}$ \\
CMSXS3722 & $\mathrm{R}$ & $\mathrm{R}$ & $\mathrm{R}$ & $\mathrm{R}$ & $\mathrm{R}$ & $\mathrm{R}$ \\
CMSXS3742 & $\mathrm{R}$ & $\mathrm{R}$ & $\mathrm{R}$ & $\mathrm{R}$ & $\mathrm{R}$ & $\mathrm{R}$ \\
CMSXS3752 & $\mathrm{R}$ & $\mathrm{R}$ & $\mathrm{R}$ & $\mathrm{R}$ & $\mathrm{R}$ & $\mathrm{R}$ \\
CMSXS3762 & $\mathrm{R}$ & $\mathrm{R}$ & $\mathrm{R}$ & $\mathrm{R}$ & $\mathrm{R}$ & $\mathrm{R}$ \\
CMSXS3772 & $\mathrm{R}$ & $\mathrm{R}$ & $\mathrm{R}$ & $\mathrm{R}$ & $\mathrm{R}$ & $\mathrm{R}$ \\
CMSXS178 & $\mathrm{R}$ & $\mathrm{R}$ & $\mathrm{S}$ & $\mathrm{R}$ & $\mathrm{R}$ & $\mathrm{R}$ \\
CMSXS201 & $\mathrm{R}$ & $\mathrm{R}$ & $\mathrm{R}$ & $\mathrm{R}$ & $\mathrm{R}$ & $\mathrm{S}$ \\
CMSXS169 & $\mathrm{R}$ & $\mathrm{S}$ & $\mathrm{S}$ & $\mathrm{S}$ & $\mathrm{R}$ & $\mathrm{R}$ \\
CMSXS3732 & $\mathrm{R}$ & $\mathrm{S}$ & $\mathrm{S}$ & $\mathrm{S}$ & $\mathrm{R}$ & $\mathrm{R}$ \\
CMSXS204 & $\mathrm{S}$ & $\mathrm{S}$ & $\mathrm{R}$ & $\mathrm{R}$ & $\mathrm{S}$ & $\mathrm{R}$ \\
CMSXS211 & $\mathrm{R}$ & $\mathrm{S}$ & $\mathrm{R}$ & $\mathrm{S}$ & $\mathrm{S}$ & $\mathrm{S}$ \\
CMSXS202 & $\mathrm{R}$ & $\mathrm{S}$ & $\mathrm{S}$ & $\mathrm{S}$ & $\mathrm{S}$ & $\mathrm{S}$ \\
CMSXS214 & $\mathrm{S}$ & $\mathrm{S}$ & $\mathrm{R}$ & $\mathrm{S}$ & $\mathrm{S}$ & $\mathrm{S}$ \\
CMSXS157 & $\mathrm{S}$ & $\mathrm{S}$ & $\mathrm{S}$ & $\mathrm{S}$ & $\mathrm{S}$ & $\mathrm{S}$ \\
CMSXS203 & $\mathrm{S}$ & $\mathrm{S}$ & $\mathrm{S}$ & $\mathrm{S}$ & $\mathrm{S}$ & $\mathrm{S}$ \\
CMSXS206 & $\mathrm{S}$ & $\mathrm{S}$ & $\mathrm{S}$ & $\mathrm{S}$ & $\mathrm{S}$ & $\mathrm{S}$ \\
CMSXS212 & $\mathrm{S}$ & $\mathrm{S}$ & $\mathrm{S}$ & $\mathrm{S}$ & $\mathrm{S}$ & $\mathrm{S}$ \\
BR009 & $\mathrm{S}$ & $\mathrm{S}$ & $\mathrm{S}$ & $\mathrm{S}$ & $\mathrm{S}$ & $\mathrm{S}$ \\
\hline R & & & & &
\end{tabular}

${ }^{1}$ - R = Resistant; $\mathrm{S}=$ Susceptible

2- Sorghum hybrid

lesions. These genotypes were also resistant in the greenhouse evaluations. Genotypes CMSXS201 (Table 3), and CMSXS178 (Table 4), susceptible to only one race in the greenhouse, exhibited no susceptible symptoms in the field. On the other hand, CMSXS213, in 1998 (Table 3), and

TABLE 3 - Area under anthracnose progress curves of 12 sorghum (Sorghum bicolor) genotypes at Sete Lagoas, measured at three distances from a source of inoculum. Experiment I

\begin{tabular}{lcc}
\hline \hline \multirow{2}{*}{ Cultivar } & \multicolumn{2}{c}{ AUDPC $^{1}$} \\
\cline { 2 - 3 } & $\mathbf{1 9 9 8}$ & $\mathbf{1 9 9 9}$ \\
\hline CMSXS203 & $1968,2 \mathrm{a} 1$ & $1622,8 \mathrm{a}$ \\
BR009 & $1764,0 \mathrm{a}$ & $1681,2 \mathrm{a}$ \\
CMSXS206 & $1173,7 \mathrm{~b}$ & $1118,8 \mathrm{~d}$ \\
CMSXS214 & $1145,7 \mathrm{~b}$ & $998,7 \mathrm{de}$ \\
CMSXS202 & $1108,3 \mathrm{~b}$ & $879,7 \mathrm{e}$ \\
CMSXS212 & $1083,8 \mathrm{~b}$ & $1453,7 \mathrm{~b}$ \\
CMSXS211 & $625,3 \mathrm{c}$ & $1005,7 \mathrm{~d}$ \\
CMSXS204 & $621,8 \mathrm{c}$ & $1289,2 \mathrm{c}$ \\
CMSXS213 & $425,8 \mathrm{~cd}$ & $91,0 \mathrm{f}$ \\
CMSXS208 & $101,0 \mathrm{~d}$ & $91,0 \mathrm{f}$ \\
CMSXS201 & $84,0 \mathrm{~d}$ & $84,0 \mathrm{f}$ \\
CMSXS210 & $84,0 \mathrm{~d}$ & $91,0 \mathrm{f}$ \\
\hline
\end{tabular}

\footnotetext{
- Means within a column followed by the same letter are not significantly different
} based on Duncan's test $(P=0,05)$
TABLE 4 - Area under anthracnose progress curves of 12 sorghum (Sorghum bicolor) genotypes at Sete Lagoas, measured at three distances from a source of inoculum. Experiment II

\begin{tabular}{lcc}
\hline \hline \multirow{2}{*}{ Cultivar $^{2}$} & \multicolumn{2}{c}{ AUDPC $^{1}$} \\
\cline { 2 - 3 } & $\mathbf{1 9 9 8}$ & $\mathbf{1 9 9 9}$ \\
\hline BR009 & $1407,0 \mathrm{a} 1$ & $1704,5 \mathrm{a}$ \\
CMSXS157 & $1395,0 \mathrm{a}$ & $1564,5 \mathrm{a}$ \\
CMSXS374 & $417,7 \mathrm{~b}$ & $233,3 \mathrm{c}$ \\
CMSXS3732 & $332,5 \mathrm{c}$ & $984,7 \mathrm{~b}$ \\
CMSXS169 & $148,2 \mathrm{~d}$ & $180,3 \mathrm{~cd}$ \\
CMSXS3722 & $133,0 \mathrm{~d}$ & $155,2 \mathrm{~d}$ \\
CMSXS178 & $79,3 \mathrm{e}$ & $80,5 \mathrm{e}$ \\
CMSXS210 & $56,0 \mathrm{e}$ & $80,5 \mathrm{e}$ \\
CMSXS3752 & $56,0 \mathrm{e}$ & $70,0 \mathrm{e}$ \\
CMSXS182 & $54,8 \mathrm{e}$ & $84,0 \mathrm{e}$ \\
CMSXS3762 & $53,7 \mathrm{e}$ & $84,0 \mathrm{e}$ \\
CMSXS3772 & $52,5 \mathrm{e}$ & $80,5 \mathrm{e}$ \\
\hline
\end{tabular}

${ }^{1-}$ Means within a column followed by the same letter are not significantly different based on Duncan's test $(\mathrm{P}=0,05)$

2- Sorghum hybrid

CMSXS372 and CMSXS374 (Table 4), in the two years, despite their resistant reaction in the greenhouse, developed some susceptible lesions at the end of the season. Sorghum line CMSXS169 and hybrid CMSXS373 exhibited high dilatory resistance in the two years of evaluation. Low levels of dilatory resistance was observed on the genotypes CMSXS202, CMSXS203, CMSXS206, CMSXS212, CMSXS214 (Table 3) and CMSXS157 (Table 4) in the two years of evaluations.

Some variation in the level of dilatory resistance from year to year was observed for some genotypes. For example, CMSXS212 ranking in sixth position, according to its level of susceptibility in 1998, was the third most susceptible in 1999. This variation may have been determined by shifts in the predominance of races in the natural population of the pathogen. Despite artificial inoculation, natural infection present in the field in the two years of evaluation, could have determined the variation in the reaction of these genotypes from one year to another. Differential interaction between sorghum genotypes and isolates of $C$. graminicola has been reported for dilatory resistance in this pathosystem (Guimarães, 1998b). These results indicate that evaluation for dilatory resistance to $C$. graminicola should include races with different levels of aggressiveness and inoculated separately as incomplete vertical resistance is probably involved in this pathosystem.

The development of susceptible lesions on CMSXS213, CMSXS372, and CMSXS374 at the end of the season may possibly, be explained by the build up of new virulence phenotypes in the pathogen population due to natural infection. Shifts in populations of plant pathogens within the same cropping season have been reported for Magnaporthe grisea (Quamaruzzaman, 1970). This hypothesis is reinforced by the fact that races with virulence 


\section{R. Casela et al.}

to the resistant genotype CMSXS210 were isolated from a different nursery, at the end of the season, in experimental fields in Sete Lagoas and confirmed their virulence in greenhouse tests (not published). The presence, in the population of $C$. graminicola, of virulence to previously resistant genotypes is not an indication, however, that this resistance will not be useful in sorghum breeding programs. Certain races, despite their wider virulence spectrum, never became predominant in the pathogen population. For example, races with virulence to SC326-6 (BR005), were observed for the first time in 1986 (Casela \& Ferreira, 1987) but never reached epidemic proportions, despite the large area cultivated, at that time, to the hybrid BR300, which has SC326-6 as its male progenitor and the susceptible line BR007 as female parent.

Genotypes CMSXS178 (susceptible to race $31 \mathrm{C}$ in the greenhouse), and CMSXS201 (susceptible to race 29F) exhibited a highly resistant reaction in the field. This may possibly indicate the presence of some type of adult plant resistance in sorghum genotypes to $C$. graminicola. Adult plant resistance is defined by Vanderplank (1982) as the resistance absent in young seedlings and developed as the plant matures. It is also possible that, due to a lower fitness of these races, as the epidemic progressed, they were eliminated or reduced to a small proportion in the mixture, not enough to cause infection in those genotypes. A reduced competitive ability of races of $C$. graminicola belonging to $\mathrm{C}$ and $\mathrm{F}$ race-groups in mixtures with races in $\mathrm{A}$ and $\mathrm{B}$ groups, has been observed by the authors.

Genotypes CMSXS203, CMSXS206, CMSXS212 (Table 3), and CMSXS157 (Table 4), which exhibited low levels of dilatory resistance, were susceptible to all six races of $C$. graminicola in the greenhouse tests. On the other hand, cultivars CMSXS373 and CMSXS169 susceptible to races $31 \mathrm{~B}, 31 \mathrm{C}$, and $29 \mathrm{E}$ in the greenhouse, had high dilatory resistance in the field. It is possible that the susceptibility of these genotypes to only a portion of races inoculated in the field had some influence on these results. As pointed out by Parlevliet (1983), the use of mixture of races may lead to an underestimation of the level of horizontal resistance when a host genotype is vertically resistant to a portion of component races of the mixture. Studies involving mixtures of races of C. graminicola with different levels of virulence and sorghum genotypes with different levels of resistance are necessary to evaluate this hypothesis.

\section{LITERATURE CITED}

ALI, M.E.K. \& WARREN, H.L. Physiological races of Colletotrichum graminicola on sorghum. Plant Disease 71:402-404. 1987.
CARDWELL, K.F., COLLINS, S.D. \& FREDERIKSEN, R.A. Dilatory resistance character of sorghum hybrids as measured by area under disease progress curve. Biological and Cultural Tests 3:36. 1988.

CARDWELL, K.F., HEPPERLY, P.R. \& FREDERIKSEN, R.A. Pathotypes of Colletotrichum graminicola and seed transmission of sorghum anthracnose. Plant Disease 73:255-257. 1989.

CASELA, C.R. \& FERREIRA, A.S. Proposta de um sistema para classificação de raças de Colletotrichum graminicola, agente causal da antracnose em sorgo (Sorghum bicolor). Fitopatologia Brasileira 12:337-344. 1987.

CASELA, C.R., FREDERIKSEN, R.A. \& FERREIRA, A.S. Evidence for dilatory resistance to anthracnose in sorghum. Plant Disease 77:908-911. 1993.

CASELA, C.R. FERREIRA, A.S. \& SANTOS, F.G. Associação de virulência de Colletotrichum graminicola à resistência genética em sorgo. Fitopatologia Brasileira 23:143-146. 1998.

FERREIRA, A.S. \& WARREN, H.L. Resistance of sorghum to Colletotrichum graminicola. Plant Disease 66:773775. 1982.

GUIMARÃES, F.B., CASELA, C.R., SANTOS, F.G. \& FERREIRA, A.S. Controle da antracnose do sorgo através da utilização de mistura de cultivares. Summa Phytopathologica 24:131-135. 1998a.

GUIMARÃES, F.B., CASELA, C.R., VALE, F.X.R., ZAMBOLIM, L. \& SANTOS, F.G. Resistência dilatória a diferentes raças de Colletotrichum graminicola. Summa Phytopathologica 24:136-140. 1998b

HARRIS, H.B., JOHNSON, B.J., DOBSON, J.W. \& LUTTRELL, E.S. Evaluation of anthracnose on grain sorghum. Crop Science 4:460-462. 1964.

PARLEVLIET, J.E. Can horizontal resistance be recognized in the presence of vertical resistance in plants exposed to a mixture of pathogen races? Phytopathology 73:379. 1983. (Abstract)

QUAMARUZZAMAN, Md. \& OU, S.H. Monthly changes of pathogenic races of Pyricularia oryzae in a blast nursery. Phytopathology 60: 1266-1269. 1970.

SHARMA, H.L.A technique for identifying and rating resistance to foliar diseases of sorghum under field conditions. Proceedings Indian Academy of Science 42:278-283. 1983.

TORRES, J.C. \& VENTURA, J.A. AVACP: Um programa para calcular a área e o volume abaixo da curva de progresso de doença. Fitopatologia Brasileira 16:52-53. 1991. (Resumo)

VANDERPLANK, J.E. Host-pathogen interactions in plant diseases. Academic Press. New York. 1982. 207pp. 